\title{
MARCO POLO'S SHEEP
}

(Ovis ammon polii)

In their Checklist of Palacarctic and Indian Mammals, 1758 to 1946, issued in 1051, J. R. Ellerman and T. C. S. Morrison-Scott regard the true sheep of the Old World as all belonging to the genus Ovis and, except for the Bighorn Sheep of Siberia and Canada, all to the sub-genus Ovis also. They allow four species : Ovis ammon, the Argali ; Ovis orientalis, the Asiatic Mouflon; Ovis laristanica, the Laristan Sheep, and Ovis musimon, the Mouflon.

The central $\Lambda$ sian species is Ovis ammon, whose distribution includes mountainous regions from the Pamirs to the Altai mountains, Tibet, Mongolia and Shansi in northern China. Ovis ammon is divided into fifteen sub-species. About one of them, Ovis ammon polii, Blyth, confined to the Pamirs proper, a most interesting lecture was given to the Society on 4th December, 1956, by Licut.-Colonel E. H. Cobb, O.B.E. (Retd.), of the Indian Political Service.

Colonel Cobb told us that the story of Marco Polo's great sheep of the Pamir plateau began in 1274, when the great Italian explorer travelled from Venice right across $A$ sia to the Court of the Chinese Emperor at Pekin. In his account of that journey Marco Polo wrote :-

"There are great numbers of all kinds of wild beasts in The Pámirs; among others, wild sheep of great size, whose horns are good six palms in length. From these horns the shepherds make great bowls to eat from, and they use the horns to cnclose folds for their cattle at night."

Nenrly six centuries elapsed until 1834 when the British explorer, Burns, rediscovered these sheep; then, in 1838, Captain Wood, who explored the source of the Oxus, brought the first specimens back to England.

Colonel Cobb described the Pamirs as a great mountainous region on the borders of Russia, Afghanistan and Chincse Turkestan, a region of very high desert valleys of glacial formation, some of them 16,000 feet above sea level. There are areas of sandstone wastes and few trees but in parts an abundance of rough pasture. The climate is excedingly severe and changeable. Icy cold blizzards alternate with blistering sunshine; white snowfields give place to brown, stony plains; deserted and desolate valleys become summer alps with lowing herds and tinkling bells, or the flutes of gontherds. For more than half the 
year the whole region is covered with snow; the lakes are frozen and the passes closed.

Ovis polii are the largest sheep in the world, standing 12 hands high at the shoulder and weighing as much as 36 stone. They have greyish fleces, becoming whiter in winter, with white ruffs and feet. Their senses of smell and sight are very keen indeed. When disturbed they will not stop for great distances, perhaps ten miles; then they settle down to graze upon the dry grasses and alpine herbiage or boortza scrub. They spend long hours resting at a point of vantage from which all approaches are guarded. In winter they inhabit high, windswept mountain faces, facing south, where dry tufts of grass can be found among the rocks and stony screes.

The rut takes place about mid-December when the big rams fight, on fairly level ground, for possession of the ewes. The challengers move backwards facing each other and then charge with increasing momentum till their horns meet with a deafening crash that echoes across the vale. Charge follows charge until one contestant gives up from sheer exhaustion, leaving the other in undisputed possession. Before the rut, the big rams lic aloof from the herds at a considerable height.

The chief natural encmies of Ovis polii are the grey wolf packs which drive them into snowdrifts or corries, the old rams with very heavy heads falling an casy prey.

After his lecture Colonel Cobb showed his beautiful collection of slides made from photographs taken when he was. Political Agent at Gilgit, and some fine exhibits. A vote of thanks for a most interesting evening was then proposed by the Chairman and was unanimously adopted. 